\title{
Optimization of the parameters of three-element grinding discs due to the uniformity of concrete surface treatment for a working width smaller than the disc diameter
}

\author{
Jarosław Kalinowski ${ }^{1}$
}

\begin{abstract}
:
The process of troweling concrete surfaces has a significant impact on reducing the number of defects, increases the durability of the element and can be used to obtain the required texture and surface roughness. The troweling process is usually performed with the use of disc trowels in which the working elements rotate uniformly around the trowel axis, and the trowel axis moves in a straight line with a uniform motion. Machines of this type are efficient and reliable, therefore they are often used in industrial applications. The disadvantage of this solution is the uneven surface treatment resulting from the kinematics of the machine. The best performance is achieved by trowels with a wheel-shaped working element, because they use the full surface intended for working elements. To increase the uniformity of machining at work, a model was analyzed that changed a single circular disk by a three-element disk consisting of concentric wheel elements and two rings that can move at different rotational speeds. Such a system uses the maximum space for working elements as a full disc. Optimization of the geometry and kinematics of such a system allows to achieve the necessary technological efficiency of mashing while increasing the uniformity of machining. The use of a working width smaller than the diameter of the disk allows you to select the area of influence with the greatest uniformity of impact for a single pass of the disk.
\end{abstract}

\section{KEYWORDS:}

floating; concrete; optimization; geometric efficiency

\section{Introduction}

The final process of concrete surface treatment is the troweling process. As a result of the troweling process, the durability of concrete elements is increased, the number of defects is reduced, the surface is evenly rough and the surface looks aesthetically pleasing. In the case of large industrial processes, such as flooring and prefabricated elements, disc floats are used. These devices are characterized by: a simple structure, high efficiency, high durability and reliability $[1,2]$. The disadvantage of these devices is the uneven surface treatment. As a parameter that determines the intensity of the treatment in the troweling process, the geometrical efficiency $\mathrm{S}_{\mathrm{g}}$ is defined as the length of the line of contact of the point of the treated surface with the working element.

The axis of rotation of the power trowel moves in a uniform, rectilinear motion, and the disc elements attached to this axis move in a uniform rotary motion. As a result of the combination of movements after the disk passes, there is a variable amount of geometric effectiveness in the direction perpendicular to the movement of the trowel axis. The standard deviation index $\varepsilon$ of the geometric efficiency $S_{g}$ measured on the measuring section was adopted as a measure of

1 Czestochowa University of Technology, Faculty of Civil Engineering, ul. Akademicka 3, 42-218 Częstochowa, e-mail: jaroslaw.kalinowski@pcz.pl, orcid id: 0000-0001-8922-4788 
the machining uniformity. The measuring section is placed on the machining width l perpendicular to the movement of the trowel axis. A smaller value of the standard deviation $\varepsilon$ of the geometrical efficiency $S_{g}$ means greater uniformity of the machining.

The relationships between the geometrical effectiveness $S_{g}$ and the roughness of the troweled surface are known for different consistencies of the troweled concrete mix [3, 4]. Solid discs with a circular-shaped working element are most often used for troweling. They have the highest average value of geometric efficiency due to the maximum use of the surface of the working element that fits in the diameter of the disc. The adjustment of the treatment intensity $\mathrm{S}_{\mathrm{g}}$ as well as the distribution of the treatment intensity on the surface is possible by using working elements of other shapes, for example four blades. This always results in a decrease in the mean value of $\mathrm{S}_{\mathrm{g}}$. In the case of machining areas with a width smaller than the width of the disk, which is the subject of this work, it is possible to select the machining area of the disk l with the width of the machined surface, e.g. a prefabricated element with the greatest uniformity of machining in the range of the disk diameter. This makes it possible to significantly increase the machining uniformity by eliminating areas close to the machining limits where the $\mathrm{S}_{\mathrm{g}}$ value is reduced to zero. In [5], two-element disks in the form of a circle and concentric ring were analysed, and in [6], three-element disks in the form of a circle and concentric rings were analysed, showing a significant increase in the uniformity of machining in relation to the full disk. The aim of this study was to check the possibility of optimizing the geometry and kinematics of the three-element wheel with regard to the uniformity of machining for the required average machining efficiency at machining widths smaller than the diameter of the shield. The use of optimized disc parameters allows for obtaining specific roughness and the highest homogeneity of the treated surface with minimal energy consumption.

\section{Model of a three-element disc consisting of elements with a common axis of rotation}

The shield shown in Figure 1 is composed of three working elements with a common axis of rotation. In the central part there is a circular working element surrounded by two rings. There is a constant distance $g$ between the working elements, which allows individual elements to rotate around a common axis without contact with each other.

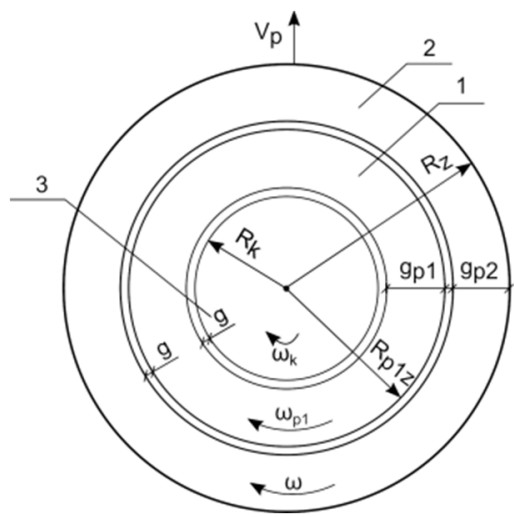

Fig. 1. Diagram of a three-element grinding disc with a central axis of rotation consisting of three working elements of the middle ring (1), the outer ring (2) and the wheel (3) that can move at independent angular velocities

For the analysis, the parameters of a trowel with a full disc with radius $\mathrm{R}_{\mathrm{z}}=0.4 \mathrm{~m}$ moving with the forward speed $V_{p}=0.1 \mathrm{~m} / \mathrm{s}$, rotational speed $\omega=-8.8 \mathrm{rad} / \mathrm{s}(-84 \mathrm{rpm}$, the disc rotates turn right). 
The following assumptions were made for the three-element blade intended to replace the above-mentioned trowel system:

- the outer radius of the outer ring is equal to the radius of the full disc $R_{z}$,

- the rotational speed of the outer ring corresponds to the rotational speed of the reference disk $\omega$,

- the distances between the individual working elements of the disc are $\mathrm{g}=1 \mathrm{~mm}$,

- the rotational speeds of the inner ring and the circular element are limited so that the maximum linear speed of these elements is not greater than the maximum linear speed of the outer ring.

Determining the geometry and kinematics of the model from Figure 1, in addition to the previously discussed four parameters $V_{p}, R_{z}, \omega$, g treated as constants, requires the determination of four additional parameters that are variables during optimization:

$\mathrm{R}_{\mathrm{k}}$ - radius of the circular workpiece,

$\mathrm{R}_{\mathrm{p} 1 \mathrm{z}}$ - outer radius of the center ring,

$\omega_{\mathrm{k}}$ - angular velocity of the circular working element,

$\omega \mathrm{p} 1$ - angular velocity of the center ring.

The geometric dependencies resulting from the diagram in Figure 1 are determined by the formulas:

$$
\begin{gathered}
R_{p 1 z}=R_{k}+g+g_{p 1} \\
R_{z}=R_{k}+g_{p 1}+g_{p 2}+2 g
\end{gathered}
$$

where: $g_{\mathrm{p} 1}$ - inner ring width, $\mathrm{g}_{\mathrm{p} 2}$ - outer ring width, $\mathrm{g}$ - distance between working elements.

Due to the variable limits of the values of geometric parameters, which must be met by dependencies (1) and kinematic, the use of optimization procedures is troublesome and it is worth looking for a description of the system based on parameters assuming values within fixed limits of the intervals [7].

The system has been defined based on four substitute parameters with fixed limit values:

$\mathrm{w}_{\mathrm{rk}}$ - coefficient determining the radius of the wheel to the radius of the disc, which can range from 0 to 0.95 ,

Wgp1 - thickness coefficient of the middle ring in relation to the remaining space in the disc, taking into account the radius of the center circle $R_{k}$ and the distance between the elements $g$, which can take values from 0 to 0.95 ,

$\mathrm{w}_{\omega \mathrm{k}}$ - coefficient defining the ratio of the maximum linear speed of the wheel to the maximum linear speed of the outer ring, which may have values from -1.0 to 1.0 ,

$\mathrm{W}_{\omega \mathrm{p} 1} \mathrm{-a}$ factor defining the proportion of the maximum linear speed of the center ring to the maximum linear speed of the outer ring, which may have a value from -1.0 to 1.0 .

The conversion of the above-mentioned coefficients into physical values can be performed using the following dependencies:

$$
\begin{gathered}
R_{k}=w_{r k} \cdot\left(R_{z}-2 g\right) \\
g_{p 1}=w_{g p 1}\left(R_{z}-R_{k}-2 g\right) \\
g_{p 2}=R_{z}-R_{k}-g_{p 1}-2 g \\
\omega_{k}=w_{\omega k} \frac{\omega_{z} \cdot R_{z}}{R_{k}} \\
\omega_{p 1}=w_{\omega p 1} \frac{\omega_{z} \cdot R_{z}}{R_{p 1}}
\end{gathered}
$$

\section{Surface treatment with a circular workpiece}

The scheme of determining the resultant velocity for the point $P(x, y)$ in the area of influence of a circular working element where the origin of the coordinate system is the center of the working element is shown in Figure 2. 


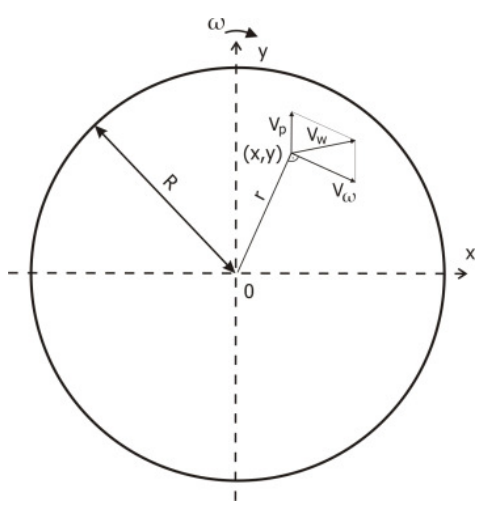

Fig. 2. Scheme of determining the vector of the resultant velocity resulting from the translational and rotational speed of the disc for any point coordinated with the center of the disc [4]

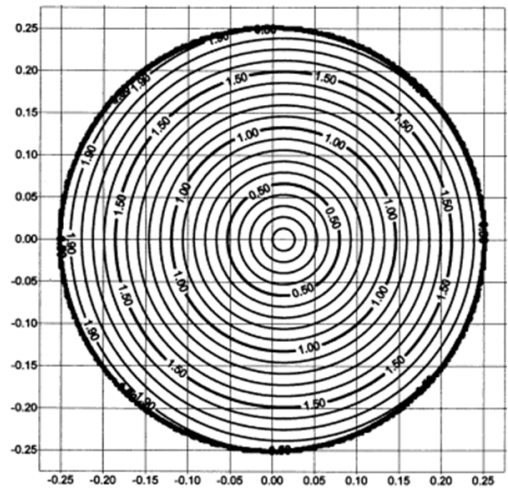

Fig. 3. The distribution of the processing speed over the entire surface of the disc $\mathrm{D}=0.5 \mathrm{~m}$ $\mathrm{V}_{\mathrm{p}}=0.1 \mathrm{~m} / \mathrm{s}, \omega=-7.54 \mathrm{rad} / \mathrm{s}[4]$

The speed at the point $\mathrm{P}$ is determined by determining the vector sum of the translational speed $V_{p}$ and the linear velocity $V_{\omega}$ resulting from the rotational speed $\omega$ (Fig. 2), which is determined by the formula:

$$
V_{w}(x, y)=\sqrt{V_{p}^{2}+2 V_{p} x \omega+y^{2} \omega^{2}+x^{2} \omega^{2}}
$$

The forward speed $V_{p}$ within the entire working element has a constant value, direction and sense, while the speed value $V_{\omega}$ is directly proportional to the distance from the center of the wheel and rotational speed $\omega$, and its direction is perpendicular to the radius of the leading point $\mathrm{P}$. The kinematic system gives the distribution of the speed values the resultant according to formula (3).

The $S_{\mathrm{g}}$ value after the target has passed the point completely is given by the following formula

$$
S_{g}(x)=\int_{t_{p}}^{t_{k}} V_{w}(x, t) d t
$$

where: $t_{p}$ - time of the beginning of contact of the point with the disc, $t_{k}-$ time of ending contact of the point with the disc, $\mathrm{x}$ - abscissa of the tested point in the coordinate system centered in the center of the target as in Figure 1.

After integration, formula (4) takes the form:

$$
\begin{gathered}
S_{g}(x)=\frac{1}{V_{p}} \sqrt{\left(R^{2}-x^{2}\right)\left(V_{p}^{2}+2 V_{p} \omega x+\omega^{2} R^{2}\right)}+ \\
+\frac{\left(V_{p}+x \omega\right)^{2}}{2 \omega V_{p}} \ln \left(\frac{\sqrt{V_{p}^{2}+2 V_{p} \omega x+\omega^{2} R^{2}}+\omega \sqrt{R^{2}-x^{2}}}{\sqrt{V_{p}^{2}+2 V_{p} \omega x+\omega^{2} R^{2}}-\omega \sqrt{R^{2}-x^{2}}}\right)
\end{gathered}
$$

Formula (5) can be used within limits $x \notin(-R ; R), V_{p}>0 \mathrm{i} \omega \neq 0$.

For $x \notin(-R ; R)$ the analyzed points are outside the target area of influence, therefore the value of the geometric effectiveness is $S_{g}=0$.

For the forward speed $V_{p}=0$, the center of the disc does not move, so the value of the geometric efficiency is infinitely large or equal to zero for the point under the axis of rotation of the disc. For the rotational speed $\omega=0$, the contact curve of the point with the target is a segment 
which is a chord of a circle, the length of which depends on the abscissa $\mathrm{x}$, which is determined by the formula:

$$
S_{g}(x)=2 \sqrt{R^{2}-x^{2}}
$$

A detailed derivation of the above-mentioned formulas is presented in [8].

\section{Geometric efficiency of the annular element}

The geometrical efficiency of the ring element can be calculated from the superposition by subtracting from the geometrical efficiency of the circle with the outer radius of the ring the effectiveness of the circle with a radius equal to the radius of the inner ring, which is given by the formula:

$$
S_{g}=S_{g R z}-S_{g R w}
$$

where: $S_{g R z}$ - geometric efficiency calculated for a circle with radius $\mathrm{R}_{\mathrm{z}}, S_{g R w}$ - geometric efficiency calculated for a circle with radius $\mathrm{R}_{\mathrm{w}}$.

After substituting dependence (5) in formula (7), we obtain the following dependencies for $|x| \in\left(0 ; R_{w}\right)$

$$
\begin{gathered}
S_{g}(x)=\frac{1}{V_{p}}\left(\sqrt{\left(R_{Z}^{2}-x^{2}\right)\left(V_{p}^{2}+2 V_{p} \omega x+\omega^{2} R_{Z}^{2}\right)}-\sqrt{\left(R_{w}^{2}-x^{2}\right)\left(V_{p}^{2}+2 V_{p} \omega x+\omega^{2} R_{w}^{2}\right)}\right)+ \\
+\frac{\left(V_{p}+x \omega\right)^{2}}{\omega V_{p}} \ln \left(\frac{\sqrt{V_{p}^{2}+2 V_{p} \omega x+\omega^{2} R_{Z}^{2}}+\omega \sqrt{R_{Z}^{2}-x^{2}}}{\sqrt{V_{p}^{2}+2 V_{p} \omega x+\omega^{2} R_{w}^{2}}+\omega \sqrt{R_{w}^{2}-x^{2}}}\right)
\end{gathered}
$$

for $|x| \in\left(R_{w} ; R_{z}\right)$ the formula takes the form analogous to that for a circle

$$
\begin{gathered}
S_{g}=\frac{1}{V_{p}} \sqrt{\left(R_{Z}^{2}-x^{2}\right)\left(V_{p}^{2}+2 V_{p} \omega x+\omega^{2} R_{z}^{2}\right)}+ \\
+\frac{\left(V_{p}+x \omega\right)^{2}}{2 \omega V_{p}} \ln \left(\frac{\sqrt{V_{p}^{2}+2 V_{p} \omega x+\omega^{2} R_{Z}^{2}}+\omega \sqrt{R_{Z}^{2}-x^{2}}}{\sqrt{V_{p}^{2}+2 V_{p} \omega x+\omega^{2} R_{Z}^{2}}-\omega \sqrt{R_{Z}^{2}-x^{2}}}\right)
\end{gathered}
$$

for $|x|>R_{Z}$ the value of the geometric efficiency is $S_{g}=0$.

\section{Geometric efficiency of complex ring-ring systems with a common axis of rotation}

For the considered ring-circular system, as shown in Fig. 1, the geometric efficiency can be calculated by summing the geometric efficiency of all working elements, which is determined by the formula:

$$
S_{g}(x)=\sum_{i=1}^{n} S_{g i}(x)
$$

where: $S_{g i}(x)$ - geometrical efficiency of the i-th element for the abscissa x. 


\section{Assessment of the uniformity of the shield impact}

The uniformity of the distribution of the effect $S_{g}$ is determined by the standard deviation index calculated for $\mathrm{n}$ values evenly distributed over the measuring section by the formula:

$$
\varepsilon=\frac{\sigma_{S_{g}}}{\overline{S_{g}}}=\sqrt{\frac{\frac{1}{2}\left(S_{g 1}-\overline{S_{g}}\right)^{2}+\sum_{i=2}^{n-1}\left(S_{g i}-\overline{S_{g}}\right)^{2}+\frac{1}{2}\left(S_{g n}-\overline{S_{g}}\right)^{2}}{{\overline{S_{g}}}^{2}(n-1)}}
$$

\section{Optimization of the parameters of the discs for machining areas with a width smaller than the diameter of the disc}

The climbing algorithm was used to optimize the parameters of the targets, which after testing turned out to be the most effective in solving the problem due to the nature of the function characterized by a large number of local minima. The shield model was generated on the basis of four parameters $w_{\mathrm{rk}}, \mathrm{w}_{\mathrm{gp} 1}, \mathrm{w}_{\omega \mathrm{k}}, \mathrm{w}_{\omega \mathrm{p} 1}$. A measuring section of the intended length $\mathrm{l}$ was placed on the machining field with the width of the disc, the position of which was determined by the distance $\mathrm{x}_{\mathrm{p}}$ measured from the left edge of the disc interaction to the beginning of the measuring section as in Figure 4. The value of $x_{p}$ was optimized for the current disc configuration. The mean value $S_{g}$ and the standard deviation index were calculated on the measuring section, the minimization of which was a function of the optimization algorithm goal. When the mean value of $\mathrm{S}_{\mathrm{g}}$ was reached beyond the assumed range, a penalty function was used to increase the value of $\varepsilon$.

The optimization was carried out for the required values of geometric efficiencies of 2, 5, 8, $11,14 \mathrm{~m}$ with the assumption that its value cannot deviate by more than $0.1 \mathrm{~m}$. The machining lengths were specified in the range from $0.1 \mathrm{~m}$ to $0.8 \mathrm{~m}$ disc diameter in increments of $0.01 \mathrm{~m}$. The optimization results are shown in Figures 5-11. Figure 5 shows a graph of the standard deviation $\varepsilon$ indicating the uniformity of the impact depending on the width of the treatment and the required average value of geometric efficiency. Figures 6 to 10 show the parameters that allow to calculate the physical geometrical and kinematic values of the disc according to the formulas (2). Figure 11 shows the achieved $\mathrm{S}_{\mathrm{g}}$ values depending on the assumed machining width.

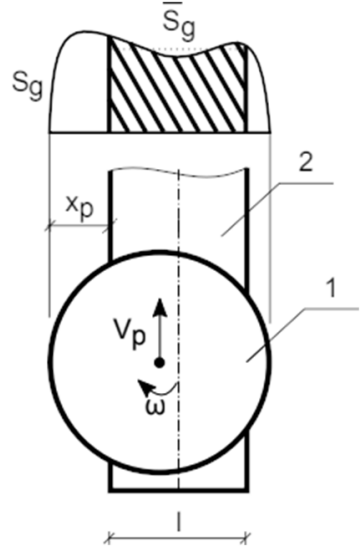

Fig. 4. Scheme of setting the disc in relation to the machining area with a width of $\mathrm{l}$ : 1 - mashing disc, 2 - prefabricated element [4]

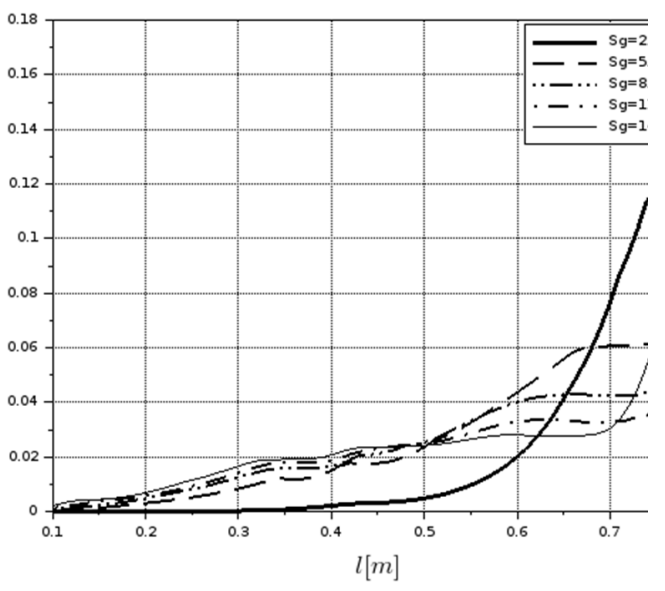

Fig. 5. Graph of the standard deviation index $\varepsilon$ in the optimally selected mashing range depending on the width of the 1 treatment bandwidth and the required minimum $S_{g}$ value for a three-element wheel 


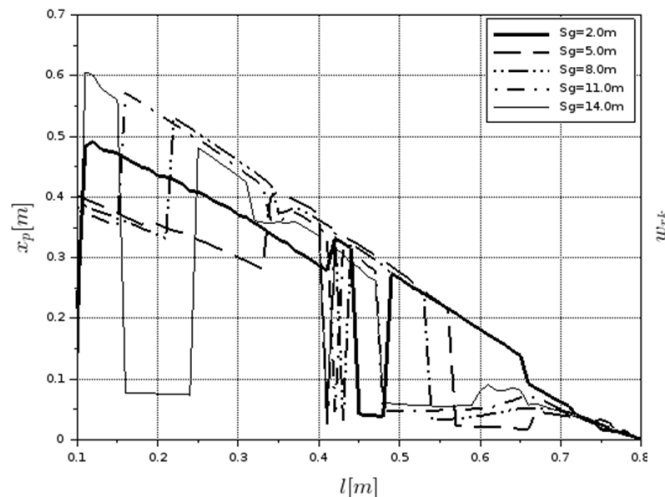

Fig. 6. Graph of the $x_{p}$ shift of the position of the three-piece disk measured from the left edge of the disk to the edge of the machined surface depending on the width of the machining band $\mathrm{l}$ and the required $\mathrm{S}_{\mathrm{g}}$ value

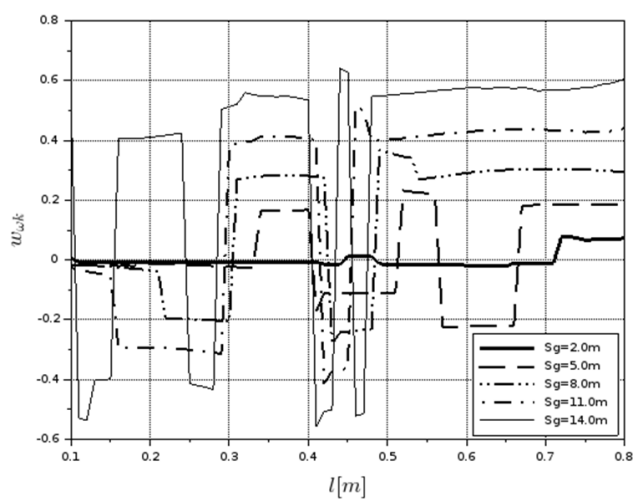

Fig. 8. Graph of the $\mathrm{w}_{\omega \mathrm{k}}$ coefficient determining the ratio of the maximum linear speed resulting from the wheel rotation to the maximum linear speed resulting from the rotation of the outer ring

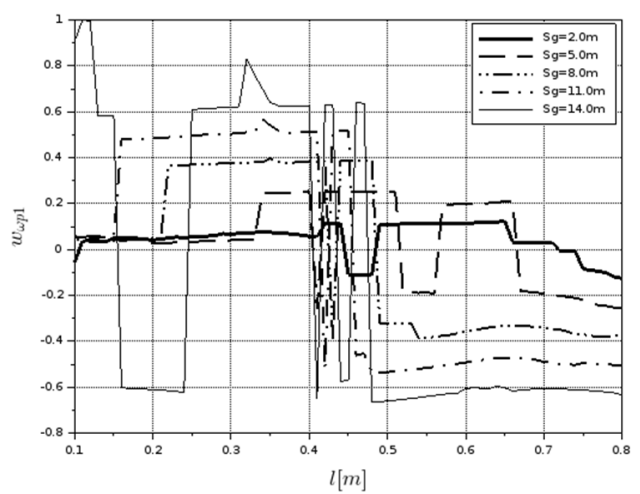

Fig. 10. Graph of the $\mathrm{w}_{\omega \mathrm{p} 1}$ coefficient determining the ratio of the maximum linear speed resulting from the rotation of the inner ring to the maximum linear speed resulting from the rotation of the outer ring

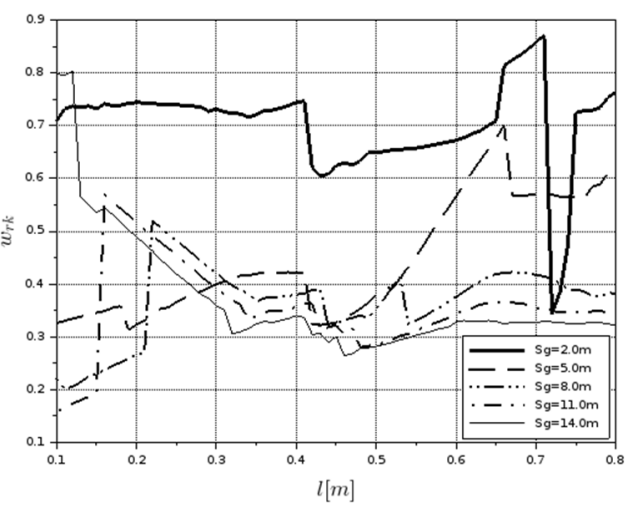

Fig. 7. Graph $\mathrm{w}_{\mathrm{rk}}$ coefficient specifying the ratio of the radius of the central working element to the radius of the disc used by the working elements

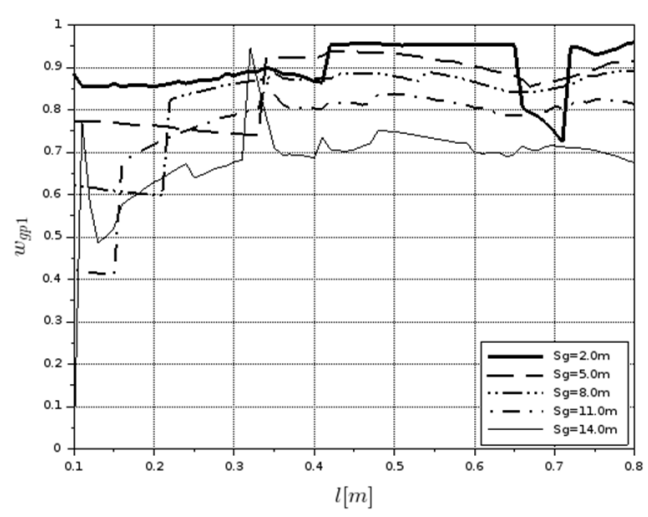

Fig. 9. Graph of the $\mathrm{w}_{\mathrm{gp} 1}$ coefficient defining the thickness of the center ring in relation to the remaining space in the disc without the radius of the center circle $R_{k}$ and the distance between the elements $2 \mathrm{~g}$

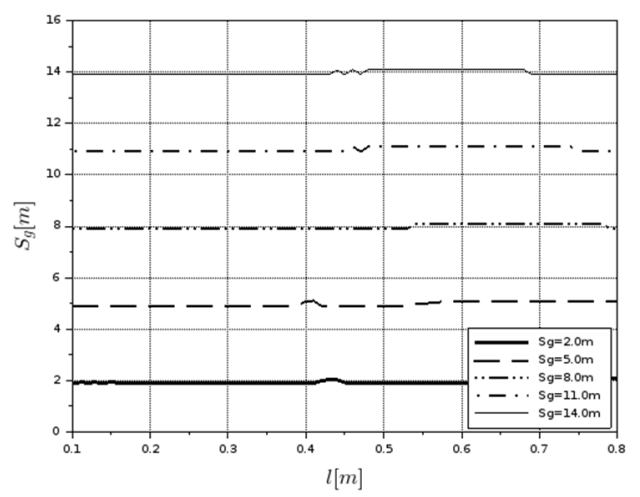

Fig. 11. Graph of the mean value of the geometric efficiency $S_{g}$ of the three-element disc obtained during optimization depending on the width of the machining bandwidth $\mathrm{l}$ and the required value of $\mathrm{S}_{\mathrm{g}}$ 


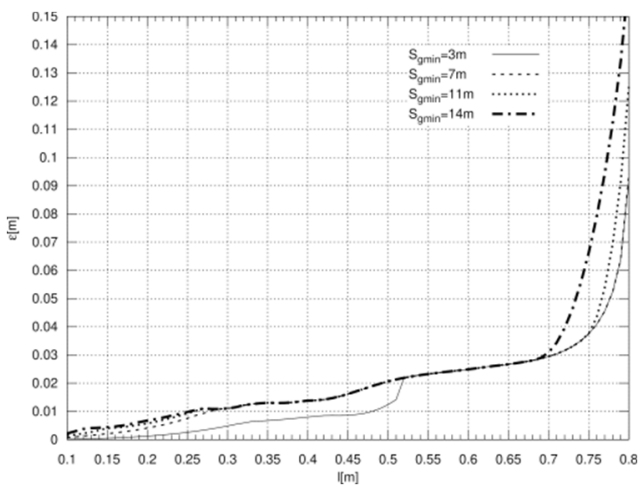

Fig. 12. Graph of the standard deviation index $\varepsilon$ in the optimally selected mashing range depending on the width of the l treatment band for a three-element wheel, assuming that the $S_{g}$ value must not be less than assumed [4]

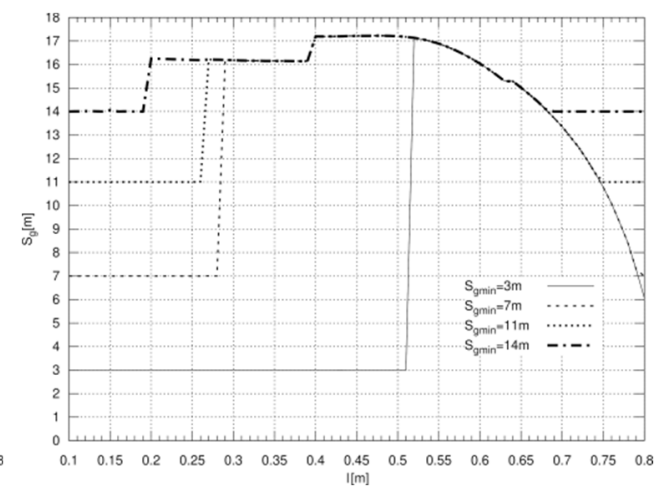

Fig. 13. Graph of the mean value of the geometric efficiency $\mathrm{S}_{\mathrm{g}}$ of a three-element disc depending on the width of the machining band $\mathrm{l}$, assuming that the $S_{g}$ value must not be less than the assumed one [4]

\section{Conclusions}

In [4], the optimization of the uniformity of mashing was carried out with the assumption of achieving the minimum average value of $\mathrm{S}_{\mathrm{g}}$. The value of the range of the achieved mean geometric effectiveness was limited only at the bottom. In this case, it is not possible to use a specific value of the average effectiveness for larger widths of the prefabricated element, as shown in Fig. 13. In the case of optimization performed in the current work, the effectiveness value is limited at the bottom and above, as shown in Fig. 11. The values of the standard deviation coefficient for the current optimization for larger working widths, l have higher values. This is due to the imposition of an additional constraint on the mean value of $S_{g}$. The standard deviation index for small processing widths up to $0.5 \mathrm{~m}$ has an increase close to linear. Above the processing width l $=0.5 \mathrm{~m}$, the gradient of the increase of the value of this indicator increases. This is due to the fact that in the case of greater machining widths, the extent of the displacement of the machining band in the area of impact of the disk is reduced. The use of several runs with overlapping machining areas would increase the uniformity of machining, but it would require additional passes, which does not meet the assumptions of this analysis. As a result of applying the methodology presented in the paper, it is possible to calculate the optimal values of the geometrical and kinematic parameters of the three-element disc. The use of the criterion of limiting the value of geometric effectiveness from the top and bottom allows for effective use of trowels for a mash width 1 greater than in the case of limitation only from the bottom, with minimal reduction of troweling uniformity. The use of specific efficiency values resulting from the need to obtain, for example, the expected roughness of the finished surface, reduces the energy requirement for the operation.

\section{References}

[1] Chrząszczewski W., Obróbka mechaniczna I obrabiarki do kamienia, h.g.BRAUNE, Jawor 2004.

[2] Tyrowicz T., Kamieniarstwo, Obróbka maszynowa, Arkady, Warszawa 1958.

[3] Rajczyk J., Podstawy naukowe doboru struktury i kinematyki tarczowych narzędzi roboczych maszyn do obróbki powierzchni betonu, Wydawnictwo Politechniki Częstochowskiej, Częstochowa 2007.

[4] Respondek Z, Rajczyk Z, Kosiń M., Jończyk D., Kalinowski J., A new method of constructing a disc for concrete surface floating, Advanced Materials Research, Xiamen 2013, 97-104.

[5] Kalinowski J., The optimization of kinematic and geometric parameters in two-element grinding discs with a central rotational axis for the uniformity of concrete surface treatment, Zeszyty Naukowe Politechniki Częstochowskiej 2019, seria Budownictwo 25, 75-85. 
[6] Kalinowski J., Optimization of Kinematic and Geometric Parameters in Three-Element Grinding Discs with a Central Rotational Axis for the Uniformity of Concrete Surface Treatment, Zeszyty Naukowe Politechniki Częstochowskiej. Budownictwo, Częstochowa 2020, s. 66-75

[7] Stadnicki J., Teoria i praktyka rozwiązywania zadań optymalizacji, WNT, Warszawa 2006

[8] Kalinowski J., Obliczanie skuteczności geometrycznej tarczy zacierającej metodą analityczną, Zeszyty Naukowe Politechniki Częstochowskiej. Budownictwo, Częstochowa 2018, s. 167-173

\section{Optymalizacja parametrów trójelementowych tarcz zacierających ze względu na równomierność obróbki powierzchni betonowych dla szerokości obróbczej mniejszej niż średnica tarczy}

\section{STRESZCZENIE:}

Proces zacierania powierzchni betonowych ma istotny wpływ na zmniejszenie ilości defektów, zwiększenie trwałości elementu i może być stosowany do uzyskania wymaganej faktury, chropowatości powierzchni. Proces zacierania wykonuje się przeważnie z pomocą zacieraczek tarczowych, w których elementy robocze obracają się jednostajnie wokół osi zacieraczki, a oś zacieraczki porusza się ruchem jednostajnym postępowym po prostej. Maszyny tego typu sa wydajne i niezawodne, dlatego są często wykorzystywane w zastosowaniach przemysłowych. Wadą tego rozwiązania jest nierównomierność obróbki powierzchni wynikająca z kinematyki maszyny. Największą wydajność osiagaja zacieraczki z elementem roboczym w kształcie koła, ponieważ wykorzystują pełną powierzchnię przeznaczoną na elementy robocze. Aby zwiększyć równomierność obróbki w pracy, analizowano model zamieniający pojedynczą tarczę kołową przez tarczę trójelementową składającą się z współśrodkowych elementów koła i dwóch pierścieni, które mogą poruszać się z różnymi prędkościami obrotowymi. Układ taki wykorzystuje maksymalnie powierzchnię na elementy robocze, jak tarcza pełna. Optymalizacja geometrii i kinematyki takiego układu pozwala osiagnąć potrzebne z punktu widzenia technologicznego skuteczności zacierania przy zwiększeniu równomierności obróbki. Wykorzystanie szerokości obróbczej mniejszej od średnicy tarczy pozwala wybrać obszar oddziaływania o największej równomierności oddziaływania przy pojedynczym przejściu tarczy.

\section{SŁOWA KLUCZOWE:}

zacieranie; beton; optymalizacja; skuteczność geometryczna 